\section{Are recurrent denture-related sores associated with the risk of oral cancer? A case control study}

\section{Há associação entre as feridas bucais por prótese dentária e risco de câncer de boca? Estudo caso-controle}

Ligia Drovandi Braga Rotundo'

Tatiana Natasha Toporcovv

Gabriela Haye Biazevic'

Marcos Brasilino de Carvalho"'I

Luiz Paulo Kowalski ${ }^{\text {iv }}$

José Leopoldo Ferreira Antunes"

'Faculdade de Odontologia, Universidade de São Paulo (SP), Brazil.

"Faculdade de Saúde Pública, Universidade de São Paulo (SP), Brazil.

"'Hospital Heliópolis, Secretaria de Estado da Saúde de São Paulo (SP), Brazil.

IVHospital A. C. Camargo - São Paulo (SP), Brazil.

Corresponding author: Tatiana Natasha Toporcov. School of Public Health, Universidade de São Paulo, Avenida Dr. Arnaldo, CEP: 715, 01246-904, São Paulo, SP, Brazil. E-mail: toporcov@usp.br Financial support: Fundação de Amparo à Pesquisa do Estado de São Paulo (FAPESP).

Conflict of interests: nothing to declare.

\section{Abstract}

Objectives: This study aimed to assess the hypothesis that recurrent denture-related sores association may be associated with the risk of oral cancer. Methods: We conducted a hospital-based case-control study comprising 71 new cases of oral cancer in two hospitals in São Paulo, Brazil, and 240 controls without cancer, recruited from outpatient units of the same hospitals. All cases had histologically confirmed squamous cell carcinoma in anatomic sites of the mouth that may be specifically considered at risk of sores by ill-fitting dentures. Denture-related sores were assessed by the self-report of recurrent oral sores due to the use of ill-fitting complete removable dental prosthesis. Associations were assessed by multivariate logistic regression conditioned on socio-demographic and behavioral characteristics. Results: The association between ill-fitting dentures and oral cancer was statistically significant in the multivariate model: odds ratio $3.98 ; 95 \%$ confidence interval 1.06 - 14.96. The specific assessment of association between tumors in the lower jaw and sores by mandibular dentures confirmed this result: odds ratio 6.39; 95\% confidence interval 1.49 - 29.52 . Conclusion: The potential contribution of denture-related sores to oral carcinogenesis still fuels controversies. This study reinforces the hypothesis that recurrent denturerelated sores may be associated with the risk of oral cancer. Results reported here also suggest that an appropriate application and monitoring of dental prosthesis represent a non-negligible scope for cancer prevention.

Keywords: Epidemiology. Mouth neoplasms. Dentures. Case-control studies. Risk factors. Oral ulcer. 


\section{Resumo}

Objetivo: O presente estudo avaliou a associação entre as feridas recorrentes por prótese dentária mal adaptada e o risco de câncer bucal. Metodologia: Foi realizado estudo caso-controle de base hospitalar que incluiu 71 pacientes com câncer bucal atendidos em dois hospitais da cidade de São Paulo, Brasil. O grupo controle foi composto por 240 pacientes sem câncer, atendidos em ambulatórios diversos dos mesmos hospitais. Todos os casos receberam diagnóstico histológico de carcinoma epidermoide em localizações anatômicas da boca sujeitas a feridas pelo uso de prótese mal adaptada. As feridas decorrentes do uso de prótese mal adaptada foram avaliadas por meio do autorrelato dos pacientes. A análise utilizou modelos de regressão logística não condicional multivariada. Resultados: A associação entre feridas por prótese mal-adaptada e câncer de boca mostrou-se estatisticamente significante no modelo multivariado: OR 3.98; IC95\% 1.06 - 14.96. A avaliação específica dos tumores da mucosa inferior confirmou esse resultado (OR 6.39; IC95\% 1.49 - 29.52). Conclusão: A contribuição do uso de próteses mal-adaptadas para a carcinogênese bucal ainda é controversa. $O$ presente estudo confirma a hipótese de que as feridas recorrentes pelo uso de próteses mal-adaptadas podem estar associadas ao risco de câncer bucal. Os resultados encontrados sugerem que a avaliação profissional regular das próteses dentárias pode ser importante para a prevenção do câncer.

Palavras-chave: Epidemiologia. Neoplasias bucais. Dentaduras. Estudos caso-controle. Fatores de risco. Úlceras orais.

\section{Introduction}

Oral cancer incidence is an important problem of public health. About 263,900 new cases of oral cancer and 128,000 deaths were estimated for 2008 worldwide. ${ }^{1}$ Tobacco and alcohol are acknowledged to be the main behavioral risk factors for oral cancer $^{1-3}$. Dietary habits, such as a low intake of fruits and raw vegetables, have also been associated with the disease 4 . Gum bleeding, periodontal disease and poor oral hygiene have been assessed as factors that may be associated with tumors of the oral cavity ${ }^{5-8}$.

The use of complete dentures by edentulous people has been reported to be safe and unrelated to the risk of intra-oral cancer $^{5,}$ butfew studies assessing the quality of the denture fitting were perfomed until now $^{9,10}$. In a study performed in Sweden the use of poorly fitting complete dentures was associated with and oral cancer ${ }^{9}$. Also, Vaccarezza et al., in a study performed in Brazil, found associations between the selfreport of sores by ill-fitting dentures and oral cancer ${ }^{10}$. In addition, a recent study found that the chronic trauma of the oral mucosa could be a risk factor for oral cancer ${ }^{11}$.

This study was undertaken to assess the association between recurrent denturerelated sores and cancer in anatomic sites of the mouth that may be specifically considered at risk of developing sores due to ill-fitting dentures.

\section{Methods}

We conducted a case-control study assessing the odds of oral cancer between patients who do and who do not complain of recurrent denture related sores (either because they do not use dentures or because their denture is not ill adjusted). Participants were enrolled among patients who had been admitted to two major hospitals in the city of São Paulo (Hospital Heliópolis and Hospital A. C. Camargo) from 2006 to 2008. The study enrolled 71 new cases of histologically-confirmed squamous cell carcinoma in anatomic sites of the mouth 
that may be specifically considered at risk of developing sores due to ill-fitting dentures: lateral border of tongue (coded C02.1 in the International Classification of Diseases, 10th Revision): 16 patients; floor of mouth (C04): 25 patients; hard palate (C05.0): 16 patients; gum (C03): 7 patients; retromolar area (C06.2): 6 patients; and cheek mucosa (C06.0): 1 patient.

The control group comprised 240 individuals, frequency matched with cases by gender and age. To avoid the selection of hospital controls with a unique disease, controls were enrolled among persons that were accompanying patients without cancer, or had been attended at outpatient units (except dental or stomatology units) of the same hospitals for a wide spectrum of health complaints. Since some cancers are associated with the same risk factors of oral cancer (e.g. lung cancer is also related to tobacco smoking), individuals who presented with previous or current experience of cancer were not included as controls

Five experienced and specifically trained interviewers administered a 30-minute structured questionnaire to cases and controls. The participants were interviewed in a separate room of the health unit immediately after their clinical consultation. The questionnaire elicited information about socioeconomic status and behavioral exposures. No proxy respondents were allowed; patients with impaired speech function were not included. This study observed Brazilian and international statutes on ethics in research involving human beings. Ethical clearance was given by the research committees of the participating institutions.

Socioeconomic status was assessed by family income and measured in multiples of the Brazilian minimum wage, a national standard for measuring income, which was roughly equivalent to US $\$ 200$ per month during the study period.

The assessment of diet used an extensive food frequency questionnaire that originally had been devised for a previous study ${ }^{12}$. Two food items, fruits and deep fried foods, stratified by categories of frequency of intake, were chosen as indicative of diet quality. The assessment of fruit consumption was unspecific. Bananas, apples and oranges are some of the most frequently consumed fruits in Brazil. Deep fried foods referred to different items that are common in the Brazilian diet and rich in saturated fat. These include French fries, manioc or cassava, deep fried pastries and stuffed tidbits, high-fat hors d'oeuvres that contain animal protein.

Patients who reported that they had not smoked one or more cigarettes daily for an entire year were classified as non-smokers. The assessment of tobacco smoking considered sequential patterns of frequency, duration, and type of products consumed during the lifetime, according to a methodology that was standardized by the International Agency for Research in Cancer (IARC) ${ }^{13}$. A cigar was considered to be equivalent to four cigarettes; each pipe serving was considered to be equivalent to three cigarettes. The cumulative exposure to tobacco was measured in pack-years (number of packs of 20 cigarettes smoked per day multiplied by the number of smoking years) and subsequently stratified into three categories: non-smokers and two groups of smokers who were classified by the median value of pack-years that were consumed in the control group.

Patients who reported that they had not consumed one or more drinks on a regular monthly basis were classified as non-drinkers. The assessment of alcohol consumption also considered sequential patterns of frequency, volume, duration, and type of beverages consumed during the lifetime, according to a methodology that was standardized by the IARC $^{14}$. The cumulative exposure to alcohol was measured in grams of ethanol, considering that one liter of ethanol weighs 798 grams, and that the ethanol content by volume in beer is $5 \%, 12 \%$ in wine, $30 \%$ in liqueurs, and $40 \%$ in distilled spirits. The variable was expressed in gram-years (grams of ethanol per day multiplied by the number of 
drinking years) and subsequently stratified into three categories: non-drinkers and two groups of drinkers who were classified by the median value of gram-years consumed in the control group.

Participants were asked if they had ever worn dentures until a year before the diagnosis. Those who had worn complete dentures for less than six months prior to the diagnosis of the tumor were considered to be non-wearers, because this time interval was considered too reduced to be referred to recurrent sores of oral mucosa. Denture-related sores were assessed by the self-report of recurrent oral sores due to the use of ill-fitting complete removable dental prosthesis.

A previous study had concluded that the proportion of patients who complains of poorly fitting dentures is higher for mandibular than to maxillary dentures ${ }^{15}$. Taking this information into account, we performed a complementary assessment, specifically focusing on tumors in the lower jaw and sores that were related to the use of mandibular dentures.

The statistical analysis used unconditional logistic regression models. The fitting of multivariate models observed a conceptual framework ${ }^{16}$, in which denture wearing and the self-record of denture-related sores (predictors) were adjusted for gender and age group, and for other exposures such as covariates on socioeconomic status, tobacco and alcohol consumption, and diet (frequency of fruit and bacon intake). Categories of alcohol and tobacco consumption, as well as fruit and bacon intake, were based in the median values of controls. The subsequent assessment of patients who were wearing mandibular dentures exclusively considered patients who were affected by mandibular tumors (i.e., cancer in the floor of mouth and mandibular gum).

Associations were assessed in terms of odds ratio (OR) point and interval estimates. Two-sided p-values lower than 0.05 were considered to be indicative of a significant association between covariates and the outcome. The statistical analysis used the Stata 11.02009 software (Stata Corporation, College Station, TX, USA).

\section{Results}

The case group comprised 18 women and 53 men, with a mean age of $56.4 \pm 9.7$ (standard deviation) years. Fifteen patients had tumors in the lateral border of the tongue, 26 in the floor of the mouth, 16 in the palate, seven in the gum, five in the retromolar area and two in the cheek mucosa. More than one third $(33.8 \%)$ of cases reported the use of removable dental prosthesis.

The control group comprised 56 women and 184 men with a mean age of $55.9 \pm 10.7$ years. They were enrolled in the outpatient units of both hospitals: 118 participants were accompanying other patients than those included as cases, and have not reported any health complaint of their own. The remaining participants were undergoing treatment related to the skin (79), cardiovascular system (26), genitourinary tract (25), endocrine disorders (15), respiratory diseases (9), orthopedic conditions (8), infectious diseases (8), rheumatoid arthritis (6), plastic surgery (4) and neurological conditions (2). Near four out of each $10(40.8 \%)$ controls reported the use of removable dental prosthesis.

Table 1 summarizes the distribution of cases and controls according to income, tobacco and alcohol consumption, diet, use of complete dentures and self-report of denture-related sores. Five percent of controls and $9.9 \%$ of cases complained about denture-related sores. Crude ORs and 95\% confidence interval $(95 \% \mathrm{CI})$ estimates are reported in Table 2. Although no association between sores from ill-fitting dentures and cancer was found in the crude analysis (OR 2.09; 95\%CI 0.79 - 5.50); this association was considered to be statistically significant when the multivariate model was adjusted for behavioral exposures (OR 3.98; 95\%CI 1.06 - 14.96).

The multivariate model confirmed the statistical association between mouth 
Table 1 - Distribution of cases and controls by covariates on socioeconomic status, tobacco smoking and alcohol consumption, dietary habits and denture condition. São Paulo, Brazil, 2008.

Tabela 1 - Distribuição de casos e controles segundo condição socioeconômica, tabagismo, consumo de álcool, hábitos alimentares e uso de prótese bucal. São Paulo, Brasil, 2008.

\begin{tabular}{|c|c|c|}
\hline \multirow{2}{*}{ Covariates } & Controls & Cases \\
\hline & $\mathrm{n}(\%)$ & $\mathrm{n}(\%)$ \\
\hline \multicolumn{3}{|l|}{ Socioeconomic status } \\
\hline \multicolumn{3}{|c|}{ Family income per month: MW (1) } \\
\hline Less than 1.00 & $14(5.8)$ & $14(19.7)$ \\
\hline From 1.00 to 2.99 & $103(42.9)$ & $27(38.0)$ \\
\hline 3.00 or more & $110(45.8)$ & $27(38.0)$ \\
\hline Not informed & $13(5.4)$ & $3(4.2)$ \\
\hline \multicolumn{3}{|l|}{ Lifestyle exposures } \\
\hline \multicolumn{3}{|l|}{ Smoking: daily packs $\times$ year } \\
\hline Non-smokers & $93(38.7)$ & $8(11.3)$ \\
\hline Less than 21.0 & $73(30.4)$ & $7(9.9)$ \\
\hline 21.0 or more & $74(30.8)$ & $56(78.9)$ \\
\hline \multicolumn{3}{|c|}{ Alcohol drinking: daily g ethanol $\times$ year } \\
\hline Non-drinkers & $71(29.6)$ & $15(21.1)$ \\
\hline Less than 500 & $85(35.4)$ & $4(5.6)$ \\
\hline 500 or more & $84(35.0)$ & $52(73.2)$ \\
\hline \multicolumn{3}{|l|}{ Dietary habits } \\
\hline \multicolumn{3}{|l|}{ Fruit: weekly frequency } \\
\hline Less than 4 times & $122(50.8)$ & $48(67.6)$ \\
\hline 4 times or more frequently & $118(49.2)$ & $23(32.4)$ \\
\hline \multicolumn{3}{|c|}{ Deep fried foods: weekly frequency } \\
\hline Less than once & $131(54.6)$ & $24(33.8)$ \\
\hline Once or more & $109(45.4)$ & $47(66.2)$ \\
\hline \multicolumn{3}{|l|}{ Oral status } \\
\hline \multicolumn{3}{|l|}{ Use of removable dentures } \\
\hline No & $143(59.6)$ & $47(66.2)$ \\
\hline Yes & $97(40.4)$ & $24(33.8)$ \\
\hline \multicolumn{3}{|c|}{ Recurrent sores by ill-fitting removable dentures } \\
\hline No & $228(95.0)$ & $64(90.1)$ \\
\hline Yes & $12(5.0)$ & $7(9.9)$ \\
\hline
\end{tabular}

MW: minimum wage in Brazil, approximately US\$ 200 during the gathering of data.

SM: Salário mínimo no Brasil, aproximadamente US\$200 durante a coleta dos dados.

cancer and covariates of the study (Table 2). Family income was inversely related to disease, whereas tobacco smoking, alcohol drinking, and frequent intake of deep fried foods were associated with an increased risk. The use of dentures (irrespective of the quality of fit) was not associated with oral cancer (OR 0.67; 95\%CI 0.31 - 1.42); recurrent sores by ill-fitting dentures was directly associated with oral cancer (OR 3.98; 95\%CI 1.06 - 14.96).

The stratified assessment for tumors in the lower jaw confirmed the direct association between the disease and the self-report of sores from ill-fitting dentures. Table 3 presents the distribution of cases and controls according to all covariates. In spite of the reduced sample, the self-report of mandibular denture-related sores was associated with tumors in the lower jaw in the multivariate model (OR 6.39; 95\%CI 1.49 - 29.52) (Table 4). Conversely, only one patient in the case group complained of sores due to maxillary dentures, which prevented the specific assessment of the upper jaw. 
Table 2 - Effect of denture use and sores by ill-fitting dentures on oral cancer. São Paulo, Brazil, 2008.

Tabela 2 - Efeito do uso de próteses totais e feridas bucais por próteses dentárias na etiologia do câncer de boca. São Paulo, Brasil, 2008.

\begin{tabular}{|c|c|c|c|c|}
\hline \multirow{2}{*}{ Covariates } & OR $(95 \% \mathrm{Cl})$ & \multirow{2}{*}{$\mathrm{p}$-value } & OR $(95 \% \mathrm{Cl})$ & \multirow{2}{*}{ p-value } \\
\hline & $(1)$ & & $(2)$ & \\
\hline \multicolumn{5}{|c|}{ Socioeconomic status (2a) } \\
\hline \multicolumn{5}{|c|}{ Family income per month: MW (3) } \\
\hline Less than 1.00 & 1.00 & Reference & 1.00 & Reference \\
\hline From 1.00 to 2.99 & $0.26(0.11-0.62)$ & 0.002 & $0.23(0.10-0.56)$ & 0.001 \\
\hline 3.00 or more & $0.25(0.10-0.58)$ & 0.001 & $0.21(0.09-0.51)$ & 0.001 \\
\hline Not informed & $0.23(0.05-0.99)$ & 0.049 & $0.21(0.05-0.91)$ & 0.036 \\
\hline \multicolumn{5}{|c|}{ Lifestyle exposures (2b) } \\
\hline \multicolumn{5}{|c|}{ Smoking: daily packs $\times$ year } \\
\hline Non-smokers & 1.00 & Reference & 1.00 & Reference \\
\hline Less than 21.0 & $1.11(0.39-3.22)$ & & $0.94(0.30-2.93)$ & 0.915 \\
\hline 21.0 or more & $8.80(3.95-19.60)$ & $<0.001$ & $7.55(2.83-20.15)$ & $<0.001$ \\
\hline \multicolumn{5}{|c|}{ Alcohol drinking: daily g ethanol $\times$ year } \\
\hline Non-drinkers & 1.00 & Reference & 1.00 & Reference \\
\hline Less than 500 & $0.22(0.07-0.70)$ & & $0.32(0.09-1.14)$ & 0.078 \\
\hline 500 or more & $2.93(1.52-5.64)$ & $<0.001$ & $2.70(1.00-7.25)$ & 0.050 \\
\hline \multicolumn{5}{|c|}{ Dietary habits $(2 \mathrm{c})$} \\
\hline \multicolumn{5}{|c|}{ Fruits: weekly frequency } \\
\hline Less than 4 times & 1.00 & Reference & 1.00 & Reference \\
\hline 4 times or more & $0.50(0.28-0.87)$ & 0.014 & $0.48(0.24-0.93)$ & 0.031 \\
\hline \multicolumn{5}{|c|}{ Deep fried foods: weekly frequency } \\
\hline Less than once & 1.00 & Reference & 1.00 & Reference \\
\hline Once or more & $2.35(1.35-4.09)$ & 0.002 & $2.34(1.1--4.60)$ & 0.014 \\
\hline \multicolumn{5}{|c|}{ Oral status $(2 \mathrm{~d})$} \\
\hline \multicolumn{5}{|c|}{ Use of removable dentures } \\
\hline No & 1.00 & Reference & 1.00 & Reference \\
\hline Yes & $0.75(0.43-1.31)$ & 0.316 & $0.67(0.31-1.42)$ & 0.293 \\
\hline \multicolumn{5}{|c|}{$\begin{array}{l}\text { Recurrent sores by ill-fitting } \\
\text { removable dentures }\end{array}$} \\
\hline No & 1.00 & Reference & 1.00 & Reference \\
\hline Yes & $2.09(0.79-5.50)$ & 0.140 & $3.98(1.06-14.96)$ & 0.041 \\
\hline
\end{tabular}

(1) Crude Odds Ratio; (2) Odds Ratios and 95\% Confidence Intervals adjusted by sex, age group and covariates in the same and more distal levels; (2a) Adjusted by sex and age group; (2b) Adjusted by themselves and by sex, age group and socioeconomic status; (2c) Adjusted by themselves and by sex, age group, socioeconomic status and lifestyle exposures; (2d) Adjusted by sex, age group, socioeconomic status, lifestyle exposures and dietary habits; (3) MW: minimum wage in Brazil $\approx$ US\$200 during the gathering of data.

(1) Odds Ratio sem ajuste; (2) Odds Ratio e Intervalo de Confiança ajustados por sexo, faixa etária e covariáveis do mesmo nível e de niveis mais distais - (2a) Ajustada por sexo e faixa etária; (2b) Ajustados entre si e por sexo, faixa etaria e condição socieconomica; (2c) Ajustados entre si e por sexo, faixa etária, condição socieconomica e estilo de vida; (2d) Ajustados entre si e por sexo, faixa etária, condição socieconomica, estilo de vida e habitos alimentares; (3) SM: Salario minimo brasileiro $\approx$ US\$ 200 durante a coleta dos dados.

\section{Discussion}

This study reinforces the hypothesis that recurrent oral sores that are related to the use of ill-fitting dentures may be associated with an increased risk of malignant neoplasm in the mouth when behavioral exposures are considered. This observation is in agreement with the findings of previous studies that have been undertaken in Brazil $^{11,17}$ and worldwide ${ }^{10}$.

Denture-related sores involve chronic traumatic ulcers of the mouth epithelium. It is recognized that chronic inflammation contributes to cancer promotion $^{18}$. Persistent trauma and 
Table 3 - Distribution of controls and cases with tumors in the lower portion of the mouth according to socioeconomic status, tobacco smoking and alcohol consumption, dietary habits and denture condition. São Paulo, Brazil, 2008.

Tabela 3 - Distribuição de controles e casos com tumores na região inferior da boca segundo condição socioeconômica, tabagismo, consumo de bebidas alcoólicas, hábitos alimentares e uso de prótese dentária. São Paulo, Brasil, 2008.

\begin{tabular}{|c|c|c|}
\hline \multirow{2}{*}{ Covariates } & Controls & Cases \\
\hline & $\mathrm{n}(\%)$ & $\mathrm{n}(\%)$ \\
\hline \multicolumn{3}{|l|}{ Socioeconomic status } \\
\hline \multicolumn{3}{|c|}{ Family income per month: MW (1) } \\
\hline Less than 1.00 & $14(5.8)$ & $7(19.4)$ \\
\hline From 1.00 to 2.99 & $103(42.9)$ & $15(41.7)$ \\
\hline 3.00 or more & $110(45.8)$ & $11(30.6)$ \\
\hline Not informed & $13(5.4)$ & $3(8.3)$ \\
\hline \multicolumn{3}{|c|}{ Lifestyle exposures } \\
\hline \multicolumn{3}{|c|}{ Smoking: daily packs $\times$ year } \\
\hline Non-smokers & $93(38.7)$ & $3(8.3)$ \\
\hline Less than 21.0 & $73(30.4)$ & $3(8.3)$ \\
\hline 21.0 or more & $74(30.8)$ & $30(83.3)$ \\
\hline \multicolumn{3}{|c|}{ Alcohol drinking: daily g ethanol $\times$ year } \\
\hline Non-drinkers & $71(29.6)$ & $7(19.4)$ \\
\hline Less than 500 & $85(35.4)$ & $1(2.8)$ \\
\hline 500 or more & $84(35.0)$ & $28(77.8)$ \\
\hline \multicolumn{3}{|c|}{ Dietary habits } \\
\hline \multicolumn{3}{|c|}{ Fruit: weekly frequency } \\
\hline Less than 4 times & $122(50.8)$ & $24(66.7)$ \\
\hline 4 times or more & $118(49.2)$ & $12(33.3)$ \\
\hline \multicolumn{3}{|c|}{ Deep fried foods: weekly frequency } \\
\hline Less than once & $131(54.6)$ & $13(36.1)$ \\
\hline Once or more & $108(45.4)$ & $23(63.9)$ \\
\hline \multicolumn{3}{|c|}{ Oral status } \\
\hline \multicolumn{3}{|c|}{ Use of removable dentures } \\
\hline No & $143(59.6)$ & $24(66.7)$ \\
\hline Yes & $97(40.4)$ & $12(33.3)$ \\
\hline \multicolumn{3}{|c|}{ Recurrent sores by ill-fitting removable dentures } \\
\hline No & $228(95.0)$ & $30(83.3)$ \\
\hline Yes & $12(5.0)$ & $6(16.7)$ \\
\hline
\end{tabular}

MW: Minimum wage in Brazil approximately US\$ 200 during the gathering of data.

SM: Salário mínimo brasileiro aproximadamente US\$ 200 durante a coleta dos dados.

secondary chronic infections may induce chronic inflammation, and reactive oxygen and nitrogen species released from leukocytes and phagocytes can interact with DNA. This can result in permanent genomic damage in proliferating cells of the repeatedly damaged and regenerated tissue $^{19}$. Furthermore, the recurrent physical irritation of oral mucosa may contribute to the topical carcinogenic effect of tobacco, alcohol drinking and some food compounds in the mouth.
Denture-related sores also involve Candida-related stomatitis ${ }^{20}$. Candida adherence and colonization of denturebase materials may induce stomatitis, which is associated with epithelial dysplasia $^{21}$. In addition, oral infection by Candida $s p$ was related to candidal leukoplakia, premalignant lesions with possibly a higher potential of malignization than other types of leukoplakia ${ }^{22}$. The hypothesis that enzymes developed by yeasts of Candida albicans are capable of producing 
Table 4 - Effect of mandibular denture use and sores by ill-fitting mandibular dentures on oral cancer (tumors in the lower portion of the mouth). São Paulo, Brazil, 2008.

Tabela 4 - Efeito de prótese dentária inferior e de feridas por prótese dentária inferior mal ajustada sobre o risco de câncer bucal (tumores na região inferior da boca).

\begin{tabular}{|c|c|c|c|c|}
\hline \multirow{2}{*}{ Covariates } & OR $(95 \% \mathrm{Cl})$ & \multirow{2}{*}{ p-value } & OR $(95 \% \mathrm{Cl})$ & \multirow{2}{*}{$p$-value } \\
\hline & $(1)$ & & $(2)$ & \\
\hline \multicolumn{5}{|c|}{ Socioeconomic status (2a) } \\
\hline \multicolumn{5}{|c|}{ Family income per month: MW (3) } \\
\hline Less than 1.00 & 1.00 & Reference & 1.00 & Reference \\
\hline From 1.00 to 2.99 & $0.29(0.10-0.84)$ & 0.022 & $0.40(0.08-1.92)$ & 0.010 \\
\hline 3.00 or more & $0.20(0.07-0.60)$ & 0.004 & $0.17(0.06-0.53)$ & 0.002 \\
\hline Not informed & $0.46(0.10-2.17)$ & 0.328 & $0.40(0.08-1.92)$ & 0.252 \\
\hline \multicolumn{5}{|c|}{ Lifestyle exposures (2b) } \\
\hline \multicolumn{5}{|c|}{ Smoking: daily packs $\times$ year } \\
\hline Non-smokers & 1.00 & Reference & 1.00 & Reference \\
\hline Less than 21.0 & $1.27(0.25-6.50)$ & 0.771 & $0.84(0.15-4.75)$ & 0.847 \\
\hline 21.0 or more & $12.57(3.69-42.80)$ & $<0.001$ & $9.40(2.25-39.20)$ & 0.002 \\
\hline \multicolumn{5}{|c|}{ Alcohol drinking: daily g ethanol $\times$ year } \\
\hline Non-drinkers & 1.00 & Reference & 1.00 & Reference \\
\hline Less than 500 & $0.12(0.02-0.99)$ & 0.049 & $0.19(0.02-1.87)$ & 0.156 \\
\hline 500 or more & $3.38(1.39-8.20)$ & 0.007 & $5.18(1.23-21.89)$ & 0.025 \\
\hline \multicolumn{5}{|c|}{ Dietary habits $(2 \mathrm{c})$} \\
\hline \multicolumn{5}{|c|}{ Fruits: weekly frequency } \\
\hline Less than 4 times & 1.00 & Reference & 1.00 & Reference \\
\hline 4 times or more & $0.52(0.25-1.08)$ & 0.080 & $0.52(0.22-1.26)$ & 0.149 \\
\hline \multicolumn{5}{|c|}{ Deep fried foods: weekly frequency } \\
\hline Less than once & 1.00 & Reference & 1.00 & Reference \\
\hline Once or more & $2.13(1.03-4.40)$ & 0.042 & $1.93(0.78-4.79)$ & 0.157 \\
\hline \multicolumn{5}{|c|}{ Oral status $(2 \mathrm{~d})$} \\
\hline \multicolumn{5}{|c|}{ Use of removable dentures } \\
\hline No & 1.00 & Reference & 1.00 & Reference \\
\hline Yes & $0.74(0.35-1.54)$ & 0.419 & $1.06(0.31-3.69)$ & 0.922 \\
\hline \multicolumn{5}{|c|}{$\begin{array}{l}\text { Recurrent sores by ill-fitting } \\
\text { removable dentures }\end{array}$} \\
\hline No & 1.00 & Reference & 1.00 & Reference \\
\hline Yes & $3.8(1.33-10.87)$ & 0.013 & $6.39(1.49-29.52)$ & 0.013 \\
\hline
\end{tabular}

(1) Crude Odds Ratio; (2) Odds Ratios and 95\% Confidence Intervals adjusted by sex, age group and covariates in the same and more distal levels; (2a) Adjusted by sex and age group; (2b) Adjusted by themselves and by sex, age group and socioeconomic status; (2c) Adjusted by themselves and by sex, age group, socioeconomic status and lifestyle exposures; (2d) Adjusted by sex, age group, socioeconomic status, lifestyle exposures and dietary habits; (3) MW: minimum wage in Brazil $\approx$ US\$ 200 during the gathering of data.

(1) Odds Ratio sem ajuste; (2) Odds Ratio e Intervalo de Confiança ajustados por sexo, faixa etária e covariáveis do mesmo nível e de niveis mais distais; (2a) Ajustada por sexo e faixa etária; (2b) Ajustados entre si e por sexo, faixa etaria e condição socieconomica; (2c) Ajustados entre si e por sexo, faixa etária, condição socieconomica e estilo de vida; (2d) Ajustados entre si e por sexo, faixa etária, condição socieconomica, estilo de vida e habitos alimentares;

(3) SM: Salario minimo brasileiro $\approx$ US\$ 200 durante a coleta dos dados.

chemical carcinogens by nitrosination has also been raised ${ }^{23,24}$.

Ill-fitting dentures, especially mandibular dentures, are associated with reduced chewing performance ${ }^{25}$. This fact could lead to a reduced effect of the mechanical cleaning of oral mucosa, which occurs while chewing some foods, mainly those rich in dietary fiber ${ }^{26}$, thus allowing carcinogens from diet, tobacco and alcohol to remain adhering to the oral mucosa for longer periods.

Case-control studies provide an important tool to assess hypotheses about 
retrospective risk factors, which would otherwise remain unaccounted for in public health. Nevertheless, selection bias and recall bias are the main limitations for this type of study ${ }^{27}$.

In order to minimize selection bias among controls, we only enrolled individuals who went to the hospital as an accompanying person of other patients then those included in the group of cases, and patients who were admitted in the hospital by health complaints unrelated to the mouth (i.e., no patients were enrolled in the dental or stomatology section of the hospital). We considered patients under treatment at the dental or stomatology unit of the hospital as ineligible as controls because this group might be comprised by a higher proportion of patients with oral sores in comparison to the base population, thus reinforcing selection bias. Among the cases, we only enrolled patients who were affected by tumors that were located in the anatomic sites of the mouth that are most likely to be affected by denturerelated sores (oral cavity and lateral border of tongue). In addition, we only assessed patients in two hospitals; our sample cannot be considered representative for the city as a whole. As these criteria resulted in a limited number of patients, data from a larger number of controls were collected in an effort to have more stable measures in the multivariate analysis.

In order to reduce recall bias, interviewers were specifically trained to ask patients about the occurrence of oral sores related to dentures prior to the diagnosis of cancer. However, patients who had oral cancer may have spent some time pondering which habits or events would have contributed to the disease, and would be more likely to recall oral sores than the controls. Then, cohort studies, which would be able to clinically assess oral sores related to dentures, are needed. In our study, nearly $40 \%$ of controls and one third of cases reported having worn dentures; however, only a low proportion complained of recurrent oral sores in both groups.
This suggests that recall bias may have not been a systematic error source.

Recall bias is a limitation that is difficult to overcome in the scope of a case-control study. The experience of oral sores caused by ill-fitting dentures does not generate effective registries at population level, and clinical examinations of oral mucosa after the diagnosis of cancer cannot be considered in the assessment of etiological factors. Nonetheless, recall bias also affects the recollection of tobacco smoking and alcohol drinking (cancer patients may be more likely to recall deleterious behaviors), and the identification of such exposures as cancer risk factors relied extensively on case-control studies.

Potential confounding biases were reduced by adjusting the multivariate regression model for covariates whose association with oral cancer has been consistently reported. These covariates were socioeconomic status, tobacco smoking and alcohol drinking ${ }^{1-3,28}$. In particular, there is a complex relationship between chronic alcohol abuse and oral disease which may not be explored fully here; thus, alcoholism can lead to neglect which may manifest itself in ill-fitting dentures that cause ulcers. Studies assessing larger samples may contribute to elucidate how the association between oral cancer and recurrent oral sores relate to tobacco and alcohol consumption, by comparing groups of patients who have and who have not had previous exposure to each of these factors.

Data collection observed frequency matching for cases and controls. We were not able to perform individual pairing, which would demand the selection of one or more reference subjects with the same matching-factors (sex and age) whereas frequency matching involves the selection of an entire stratum of reference subjects with analogous matching-factors. Taking into consideration that matching by frequency requires to be controlled in the analysis, we adjusted all regression models by sex and age group. 
Dietary patterns have also been associated with oral cancer. ${ }^{11,12}$ Thus, it is important to include the intake of food items in covariates. The frequency of fruit intake is a marker of an antioxidant, fiber-rich diet, whereas the frequency of deep fried food intake is a marker of saturated fat in diet. In any event, the assessment of diet is complex, and the possibility of residual confounding due to unacquainted effects of diet on the association between oral cancer and denture-related sores cannot be ruled out.

Although it was statistically significant in the multivariate model, the association between recurrent denture sores and oral cancer was not significant in the direct, non-adjusted assessment. This observation suggests that the potential contribution of recurrent oral sores by ill-fitting dentures in carcinogenesis may be adjuvant to the concurrent exposure to tobacco, alcohol and poor dietary habits.

When the mandible was specifically assessed, the association had analogous results to those obtained in the overall analysis. This observation is consistent with the hypothesis that most of the association between oral cancer and denture-related sores may be attributed to the use of ill-fitting dentures in the lower jaw.

This study observed a higher frequency of oral sores among mandibular denture wearers. Indeed, the anatomical characteristics of the lower jaw may explain the poorer retention of a dental prosthesis. Complaints about denture stability, discomfort and pain from traumatic ulcers more commonly concern the mandible than the maxilla, and the chance of ill-adjustment has already been reported to be higher for mandibular than for maxillary dentures, whether assessed by the patient or by the dentist ${ }^{15}$.

This study supplied further evidence of the association between oral cancer and recurrent sores that are caused by ill-fitting dentures in an assessment that has been adjusted for the most relevant cancer covariates. Chronic inflammation of the oral mucosa by sore spots, Candidarelated stomatitis in denture wearers and lower chewing performance due to pain may provide plausible explanations of these results. Therefore, this study reinforces the importance of dental services for adults and the elderly.

The success of prosthetic dental treatment is multi-factorial and depends on psychological factors of the patient, the quality of denture making, and the previous status of oral, denture-bearing mucosa. Most of these factors can be achieved if adequate oral rehabilitation and patient follow-up are offered to edentulous patients ${ }^{29,30}$. In addition to improving mouth function and quality of life, the appropriate application and monitoring of dental prosthesis represent a non-negligible scope for cancer prevention.

\section{References}

1. Hashibe M, Brennan P, Benhamou S, Castellsague X, Chen $\mathrm{C}$, Curado MP, et al. Alcohol drinking in never users of tobacco, cigarette smoking in never drinkers, and the risk of head and neck cancer: pooled analysis in the International Head and Neck Cancer Epidemiology Consortium. J Natl Cancer Inst 2007; 99(10): 777-89.

2. Purdue MP, Hashibe M, Berthiller J, La Vecchia C, Dal Maso L, Herrero R, et al. Type of alcoholic beverage and risk of head and neck cancer--a pooled analysis within the INHANCE Consortium. Am J Epidemiol 2009; 169(2): 132-42.

3. Hashibe M, Brennan P, Chuang SC, Boccia S, Castellsague X, Chen C, et al. Interaction between Tobacco and Alcohol Use and the Risk of Head and Neck Cancer: Pooled Analysis in the International Head and Neck Cancer Epidemiology Consortium. Cancer Epidemiol Biomarkers Prev 2009; 18(2): 541-50.
4. World Cancer Research Fund. American Institute for Cancer Research. Food, nutrition, physical activity, and the prevention of cancer: a global perspective. Washington: WCRF/ AICR; 2007.

5. Talamini R, Vaccarella S, Barbone F, Tavani A, La Vecchia C,Herrero R, et al. Oral hygiene, dentition, sexual habits and risk of oral cancer. Br J Cancer 2000; 83(9): 1238-42.

6. Balaram P, Sridhar H, Rajkumar T, Vaccarella S, Herrero S, Nandakumar A, et al. Oral cancer in southern India: the influence of smoking, drinking, paan-chewing and oral hygiene. Int J Cancer 2002; 98(3): 440-5.

7. Michaud DS, Liu Y, Meyer M, Giovannucci E, Joshipura K. Periodontal disease, tooth loss, and cancer risk in male health professionals: a prospective cohort study. Lancet Oncol 2008; 9(6): 550-8. 
8. Meyer MS, Joshipura K, Giovannucci E, Michaud DS. A review of the relationship between tooth loss, periodontal disease, and cancer. Cancer Causes Control 2008; 19: 895-907.

9. Rosenquist K, Wennerberg J, Schildt EB, Bladström A, Göran Hansson B, Andersson G. Oral status, oral infections and some lifestyle factors as risk factors for oral and oropharyngeal squamous cell carcinoma. A populationbased case-control study in southern Sweden. Acta Otolaryngol 2005; 125(12): 1327-36.

10. Vaccarezza GF, Antunes JL, Michaluart-Júnior P. Recurrent sores by ill-fitting dentures and intra-oral squamous cell carcinoma in smokers. J Public Health Dent 2010; 70(1): 52-7.

11. Piemonte ED, Lazos JP, Brunotto M. Relationship between chronic trauma of the oral mucosa, oral potentially malignant disorders and oral cancer. J Oral Pathol Med 2010; 39(7): 513-7.

12. Toporcov TN, Antunes JL, Tavares MR. Fat food habitual intake and risk of oral cancer. Oral Oncol 2004; 40(9): 925-31.

13. International Agency for Research in Cancer. Monographs on the evaluation of carcinogenic risks to humans: tobacco smoking. Lyon: IARC; 1986.

14. International Agency for Research in Cancer. Monographs on the evaluation of carcinogenic risks to humans: alcohol drinking. Lyon: IARC; 1988.

15. Celebić A, Knezović-Zlatarić D, Papić M, Carek V, Baucić I, Stipetić J. Factors related to patient satisfaction with complete denture therapy. J Gerontol A Biol Sci Med Sci 2003; 58(10): M948-53.

16. Victora CG, Huttly SR, Fuchs SC, Olinto MT. The role of conceptual frameworks in epidemiological analysis: a hierarchical approach. Int J Epidemiol. 1997; 26(1): 224-7.

17. Velly AM, Franco EL, Schlecht N, Pintos J, Kowalski LP, Oliveira BV, et al. Relationship between dental factors and risk of upper aerodigestive tract cancer. Oral Oncol 1998; 34(4): 284-91.

18. Philip M, Rowley DA, Schreiber H. Inflammation as a tumor promoter in cancer induction. Semin Cancer Biol 2004; 14(6): 433-9.
19. Coussens LM, Werb Z. Inflammation and cancer. Nature 2002; 420(6917): 860-7.

20. Jainkittivong A, Aneksuk V, Langlais RP. Oral mucosal conditions in elderly dental patients. Oral Dis 2002; 8(4): 218-23.

21. Zomorodian K, Haghighi NN, Rajaee N, Pakshir K, Tarazooie B, Vojdani M, et al. Assessment of Candida species colonization and denture-related stomatitis in complete denture wearers. Med Mycol 2011; 49(2): 208-11.

22. Hooper SJ, Wilson MJ, Crean SJ. Exploring the link between microorganisms and oral cancer: a systematic review of the literature. Head Neck 2009; 31(9): 1228-39.

23. Johnson NW. Orofacial neoplasms: global epidemiology, risk factors and recommendations for research. Int Dent J 1991; 41(6): 365-75.

24. Krogh P, Hald B, Holmstrup P. Possible mycological etiology of oral mucosal carcinoma: catalytic potential of infecting Candida albicans and other yeasts in production of N-nitrosobenzymethylamine. Carcinogenesis 1987; 8(10): 1543-8.

25. Marshall TA, Warren JJ, Hand JS, Xie XJ, Stumbo PJ. Oral health, nutrient intake and dietary quality in the very old. J Am Dent Assoc 2002; 133: 1369-79.

26. Birkeland JM, Jorkjend L. The effect of chewing apples on dental plaque and food debris. Community Dent Oral Epidemiol 1974; 2(4): 161-2.

27. Breslow NE, Day NE. Statistical methods in cancer research. Volume I - The analysis of case-control studies. IARC Sci Publ 1980; (32): 5-338.

28. Antunes JL. Socioeconomic status and health: a discussion of two paradigms. Rev Saude Publica 2008; 42(3): 562-7.

29. Carlsson GE. Clinical morbidity and sequelae of treatment with complete dentures. J Prosthet Dent 1998; 79(1): 17-23.

30. Laurina L, Soboleva U. Construction faults associated with complete denture wearers' complaints. Stomatologija 2006; 8(2): 61-4.

Received on: 03/25/12

Final version presented on: 04/23/13 Accepted on: 06/05/13 